\title{
HEDONIC AND UTILITARIAN EFFECTS ON THE ADOPTION AND USE OF SOCIAL COMMERCE
}

\author{
Ángela Plaza-Lora (angplalor@gmail.com) \\ Ángel F. Villarejo-Ramos (curro@us.es) \\ Universidad de Sevilla \\ Departamento de Administración de Empresas y Marketing \\ Av. Ramón y Cajal, 1 \\ 41018 Sevilla (España)
}

\begin{abstract}
The aim of this research is to contribute to the field of study which explores the consumer behaviour model in social commerce, introducing the social commerce concept as a new commercial formula.

To study the acceptance and use of social commerce by consumers, we have proposed the Social Commerce Acceptance Model which brings together several models of technology acceptance, including the Technology Acceptance Model (TAM), its successor Technology Acceptance Model 2 (TAM2) and The Unified Theory of Acceptance and Use of Technology (UTAUT), and the inclusion of hedonic and utilitarian values which will help us identify the key variables influencing the intention to use social commerce.

To carry out this research, we distributed a survey answered by 486 individuals. The results obtained confirm satisfactory results on the relationships proposed, highlighting the influence of hedonic and utilitarian values on attitude and perceived usefulness.
\end{abstract}

KEYWORDS: hedonic value, utilitarian value, technology acceptance, social commerce

\section{INTRODUCTION}

Almost twenty-two years after the commercial launch of Internet, it has become one of the most important distribution channels and an infinite source of customer information (Constantinides et al., 2008). In the last years the rise of Web 2.0 and the settlement of e-commerce as an online sales platforms are changing the way we understand marketing now and therefore it has attracting the attention of practitioners and scholars.

The convergence of social media applications of the Web 2.0 and the increasing presence of e-commerce platform have led to a new commercial formula known as Social Commerce. The popularity of social commerce is increasing as a $43 \%$ per year and with this new commercial trend the $88 \%$ of companies expect to invest on social commerce in the near future (Constantinides et al., 2008), being even more influential than websites or CRM (Hajli, 2012). Online-based companies like Google or Amazon or social networking sites such as Facebook or LinkedIn have increased their service portfolio in order to implement social commerce as a commercial formula in their websites (Lee, 2014). For the modern business it is very important to have social strategies thus social commerce it is changing marketing strategies of almost every sector in the market, and this changes may influence their businesses (Stephen $\&$ Toubia, 2010).

The exploitation of the information collected from collaborative users and potential users on social commerce websites and platforms will be vital in order to maximize WOM advertising, which as it has been proved, it is less costly than traditional advertising. (Liébana-Cabanillas \& Villarejo-Ramos, forthcoming). But not only it is important for firms to adapt their businesses to social commerce in order to maximize WOM but also because it has been also proved that potential consumers trust more in other 
people's recommendations than in the recommendations made by a recommender software of a website (Hajli, 2013). The world is becoming social and therefore the organizations need to adapt to this changing pattern.

As social commerce is a fairly new innovation it becomes necessary for the organizations and as well for researchers to really understand what are the key variables what makes consumers choose this platform. Our investigation is structured in six different sections, after the introductory section, the section 2 will analyse the foundations of social commerce and how these foundations have evolve in order to converge into social commerce. In the third section we will stablished the theoretical background and the hypotheses proposed to validate the behavioural model. Section 4 describes the methodology used in the investigation and in section 5 we will analyse the results obtained. Finally, in the sixth section we will expose the conclusions, the practical implications and the limitations of this research that will be useful to take into account in future researches.

\section{CONTEXTUALIZATION OF SOCIAL COMMERCE AS A NEW TREND IN COMMERCIAL FORMULAS}

Nowadays the vast majority of the global population lives in a digital world. Internet has become a part of our lives and it is not difficult to find that a large part of our daily activities can be done online. The numerous innovations on the Internet and the settlement of the Web 2.0 have represented an important milestone in the development of this technology.

One of these innovations abovementioned is the electronic business which is changing the way enterprises behave in the modern economy. The new electronic business model allows content, community and commerce to converge (Hughes \& Breytenbach, 2013) becoming trade on the Internet one of the most important tools for the companies (Liébana-Cabanillas et al., 2014a). This change implies a revolution not only in the buying habits of consumers but also in the consumer-business relationships (Sharma and Sheth, 2004).

The development of the Web 2.0 has meant the behavioural change of the internet users whom have changed the email and search engines for information development, information upload and information sharing (Wattanasupachoke, 2011). This change is mainly caused by the way people interact online, and it is closely related to the rise of social networking sites that has allowed the interconnectivity of users (Hajli, 2013; Hajli et al., 2013) and social media. A clear example of this is that as of June 2015, the monthly active users of Facebook reach the number of 1.49 billion (Facebook, 2015). Social media has enabled users to be more active online and therefore they have become hyper-informed consumers (Hajli et al., 2013) The influence of social networks and social media on people's daily life is one of the most powerful reasons why businesses and organizations have the need to adapt their strategies to these changes in order to create competitive advantages (Wattanasupachoke, 2011) now that the information is very accessible for the customer and he or she can influence the market due to this information accessibility (Hajli et al., 2013).

Web 2.0 sites changed the way users interact with the Internet, while in what was known as Web 1.0, users where only allowed to view the content in the websites pages, the arrival of Web 2.0 allowed and allows users to interact and collaborate with other users while creating user generated content in a virtual community (Wikipedia). In the figure below are shown the key features of Web 2.0 and some examples of Web 2.0 sites.

Along with the Web 2.0 we have also highlighted the importance of trading on the Internet nowadays, this concept was broadly materialized in what is known as e-commerce. E-commerce has been conceptualized differently by numerous scholars. For Bontis and De Castro (2000) e-commerce can be summarized "as the buying and selling of goods and services via electronic means such as the Internet". For Kutiala (2003) e-Commerce is "a new way of conducting, managing and executing business transactions using modern information technology".

As we have mentioned before e-commerce has become an essential tool for the companies in order to be competitive in the actual environment. Among the advantages of e-commerce we highlight: continuous accessibility, direct contact between customers and producers, open markets, cost reductions, time savings, immediacy of interaction and the personalization and globalization of markets (Armesh et al., 
2010). One of the major changes in e-commerce according to Kim \& Srivastava (2007) was the implementation of recommender systems in order to provide the customer personalized recommendations based on previous purchases and the customer's profile and interests, but although it showed a good performance at the beginning, e-commerce websites found that the customer were far more likely to accept recommendations from people rather than from a system, this discovery marked a turning point in the way Internet trade was conceived.

We have already seen abovementioned how the appearance of Web 2.0 revolutionized the way Internet was seen. In order to clearly conceptualized social commerce as we understand it, it is becomes very necessary to have an overview of the evolution of e-commerce to clearly understand the development of social commerce.

In 1994 the Internet was launched and between this year and 1997 organizations started to have presence on the Internet, the online shopping formula was almost imperceptible as most of the companies only used their physical stores to sell their products and/or services. During these years, the Internet started to grow rapidly due to an increased interest of it, this milestone caused that some companies foreseen the online sale as a new business model which would allow them to have a competitive advantage among their competitors, that is when e-commerce was born. In the late 90 's and the early 00 's began to appear the firsts entirely Internet-based companies like e-bay and Amazon. The easiness with which these entirely Internet-based companies reach consumers in different markets and countries resulted in an increased pressure for traditional companies to increase their online presence. Internet was seen as an important commercial platform that had a key role in the businesses strategic plans (Constantinides et al., 2008).

The speculation in the stock market led to the Dotcom Bubble from 1998 to 2001 which burst in 2000 resulting in a decrease of the number of online companies, but the bubble burst did not caused any effect on the consumers behaviour regarding online purchases. It was from 2003 when sites like MySpace or Facebook rise. Initially the commercial potential of these sites were seen as insignificant by the online companies' owners. On 2005 appeared the first reference to social commerce (Yahoo!, 2005; Curty \& Zhang, 2011) coinciding with the increasing use of social networking sites and the appearance of Web 2.0.

The Customer Generated Content allowed by Web 2.0 became the main source for pro-active business to gain information about the users in order to increase customer's loyalty (Constantinides et al., 2008). This factor and the potential of social networking sites to attract capital was the trigger to officially coin the term social commerce in 2008. In fact, in less than a year, from 2007 to 2008, the Financial Times reported that the visit of shopping websites with social functionalities grew by more than 500 per cent (Liang \& Turban, 2011). Since then the growing popularity of social commerce is reaching $43 \%$ per year and nearly $88 \%$ of businesses expect to expand their investment on social commerce in the future (Constantinides et al., 2008).

Figure 1: The evolution of e-commerce to social commerce (adapted from Hughes \& Beukes, 2013)

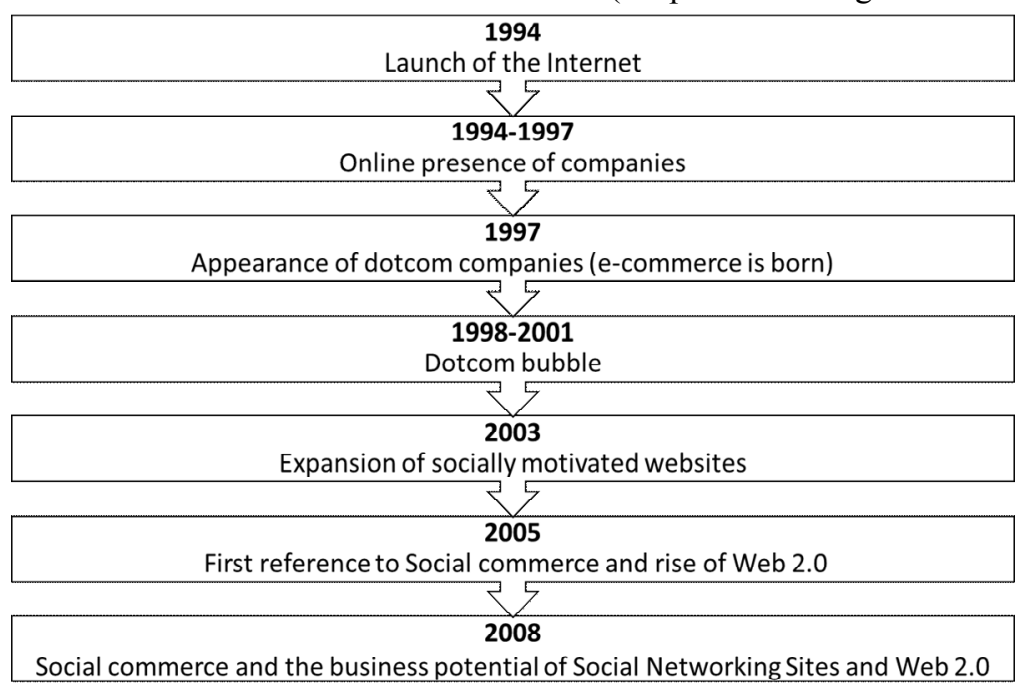


According to the evolution of e-commerce and the Internet, the convergence of Web 2.0 features and ecommerce characteristics and advantages has brought a new type of Internet trading which is known as social commerce.

Social commerce, also known as s-commerce, is a recently innovation and therefore there is not a unified concept of it. Whereas some scholars define it as a type of electronic commerce that combines sales with the customer social interaction in a social media environment (Liang \& Turban, 2011; Wang \& Zhang, 2012; Hajli, 2013; Lee, 2014), other authors proposed a concept for social commerce which is narrowed to the seller perspective, this is the case of Stephen and Toubia (2010) who believe that social commerce "is an emerging trend in which sellers are connected in online social networks, and where sellers are individuals instead of firms". This perspective is connected with the line of research in which social commerce is divided into two perspectives, the seller's and the consumer's, and in which there are two individual concepts: social commerce (seller's perspective) and social shopping (consumer's perspective) (Stephen \& Toubia, 2010).

Nevertheless, other authors consider both terms, social commerce and social shopping as analogous (Sun, 2011; Liao \& Chu, 2013). In our case, we will not consider social commerce and social shopping as equal as we have found evidences on researches in which social shopping is defined as "the enjoyment of shopping with friends and family, socializing while shopping, and bonding with others while shopping" (Hassouneh \& Brengman, 2011; Lee et al., 2013; Ozen \& Engizek, 2014) in which socialization and enjoyment are the key of the concept, and there is no evidence of interactive social relationships within the concept which lead us to think that social shopping is related with Web 2.0 or e-commerce whatsoever.

The diversity of definitions that we have yet highlighted it is not only caused by the seller's and customer's perspective but also by the involvement of multiple disciplines. When conceptualizing social commerce, disciplines like marketing, computer science, sociology and psychology have defined a concept for it (Huang \& Benyoucef, 2012). In marketing, according to Constantinides and Fountain (2008), social commerce is "a noticeable trend in online marketplaces where businesses leverage social media or Web 2.0 as a direct marketing tool to support customers' decision making processes and buying behaviour". From the computer science perspective, social commerce has been described as an application which combines Web 2.0 technologies, interactive platforms, social media and communities in a commercial environment (Lee et al., 2008). For sociology, social commerce is based on the impact of social influence used by web-based social communities from e-commerce companies (Kim \& Srivastava, 2007). Finally social commerce viewed from the psychological perspective is the influence that information collected in a networked community have on people when they perform online purchases (Marsden, 2009).

Taking into account all the considerations exposed we believe that social commerce has a wider scope in which seller's and consumer's perspectives meet in order to develop a global concept to explain social commerce. We therefore believe that social commerce combines both Business to Consumer and Consumer to Consumer approaches (Curty \& Zhang, 2011). Considering these approaches, we therefore propose the following definition for social commerce: social commerce is an Internet trading innovation in which consumers interact with each other and make contributions in order to facilitate the online buying and selling of products and/or services, allowing the consumer to make informed purchases by exchanging information with other users through reviews, ratings and comments of the products or services, thus allowing the development of synergies between customers, organizations and social networks.

As we have seen, social commerce has the potential to change the marketing strategies of companies (Lee, 2014), and therefore it becomes vital for organizations in this digital era to adapt their business models to it (Hajli, 2013). The influence of social commerce on market trends in the next years will be very important. Due to that online paradigm which is growing rapidly, we have found a need to understand the key variables that influence the adoption and usage of social commerce.

\section{THEORETICAL BACKGROUND AND HYPOTHESES}

The aim of this work is to look for a convincing technology adoption model to explain the intention to use social commerce among users. We propose the Social Commerce Acceptance Model (SCommAM), 
which is based on the classical Technology Acceptance Model posit by Davis (1989) although it also integrates other factors from the Unified Theory of Acceptance and Use of Technology (UTAUT) (Venkatesh et al., 2003), and the TAM extension, TAM2 (Venkatesh \& Davis, 2000) as well as other theories (Lu, Yao \& Yu, 2005; Zhang et al., 2011; Yang \& Lee 2010) which will help us understand the acceptance of social commerce.

\subsection{The Social Commerce Acceptance Model (SCommA)}

The research model we proposed unifies some of the key constructs in TAM, TAM2 and UTAUT as a starting point of our research and extended with additional constructs important to social commerce acceptance.

It retains the major variables of TAM: perceived usefulness, perceived ease of use, attitude and behavioural intention. It also considers the TAM2 and UTAUT social influence as subjective norms and its direct influence on perceived usefulness and behavioural intention and the moderator effect of gender and age proposed in UTAUT. But we have also consider other constructs which we believe are extremely important in order to understand not only the acceptance of social commerce but also the reason to use social commerce itself, to understand this we have also included in our research model two additional variables, hedonic value and utilitarian value to study their effect on attitude and perceived usefulness, and the moderator effect made by gender on both relationships. This will help us understand the way people use social commerce and the reason to use it

The Social Commerce Acceptance Model (SCommAM) (Figure 2) proposed is shown below.

Figure 2: Social Commerce Acceptance Model (SCommAM)

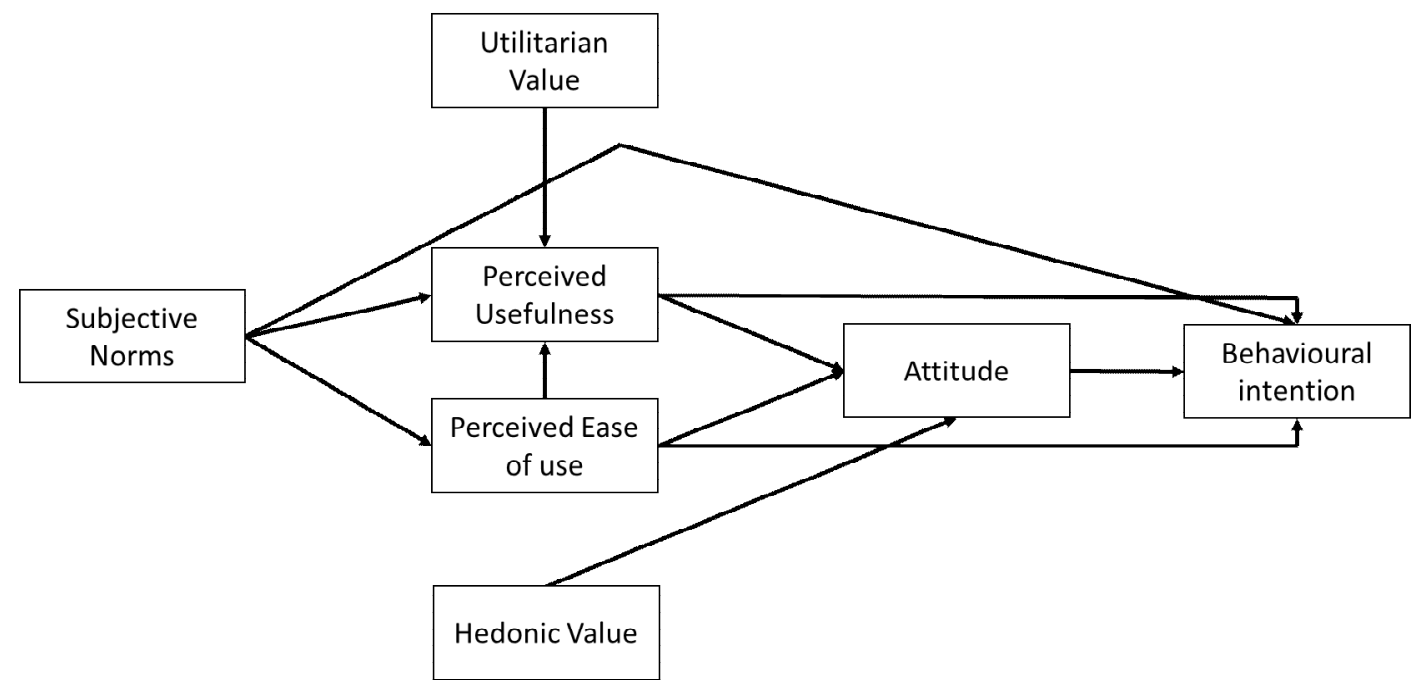

\subsection{Research hypotheses}

Subjective norms, significantly, affects the user's beliefs regarding social commerce (Cheng, 2011). Other people's opinions, peers' opinions or referent's opinions, could play an important part in the adoption process of technologies like social commerce which are in their early stages of development or diffusion (Gao \& Bai, 2014). This is one of the reasons why Davis (1989) highlighted the role of subjective norms within the IT acceptance and usage behaviour.

Subjective norms are a direct determinant of behavioural intention to use social commerce and that this construct has been used in a large number of studies (Amin, 2008; Kleijnen et al., 2004; Nysveen, 2005; Venkatesh et al., 2012) and it has been proven to be vital in the intention development to use a new technology like social commerce (Nasri \& Charfeddine, 2012; Sabir et al., 2013), we therefore propose that:

Hypothesis 1A: Subjective Norms will have a positive direct effect on the intention to use s-commerce

Subjective norms could influence the person's assessment of social commerce in terms of usefulness (Lu et al., 2005). Therefore, based on these previous findings, we propose: 
Hypothesis 1B: Subjective Norms will have a positive direct effect on the perceived usefulness of scommerce.

If the person thinks that social commerce is a difficult technology and unfriendly his or her perception about it would be negative and therefore he or she would probably not use it, but if this negative point of view is countered by his or her referents, the probability of this person using social commerce will be higher. Based on this, and previous studies (Lu et al., 2005; Bhatti, 2007), we proposed:

Hypothesis 1C: Subjective Norms will have a positive direct effect on the perceived ease of use of scommerce

Perceived ease of use refers to the perception of a person regarding the usage easiness and the level of effort to use a certain system (Davis, 1989). According to Davis (1989), the variable perceived ease of use it is very important in the acceptance of an IT system because is "the basis of a system use". According to $\mathrm{Lu}$ et al. (2005) the degree of easiness perceived by the customers is recognized to be an important determinant for using a system. In the case of social commerce, users need to feel that social commerce is easy to use in order to see the utility of it, if they do not perceived this usefulness they will use other types of internet commerce like e-commerce or mobile commerce. Therefore we expect to see a significant positive effect between perceived ease of use and perceived usefulness:

Hypothesis 2A: Perceived Ease of Use positively affects usefulness in the use of s-commerce

Perceived ease of use has a positive impact on the user's attitude towards the system as well. Direct and indirectly through its effect on perceived usefulness (Lu et al., 2005). If a person founds that a system (i.e. social commerce) is not difficult in its usage, the attitude towards the use of social commerce will be positive, and the effect will be double, because not only the person will have a positive attitude towards social commerce because it is easy to use but also because the use easiness will influence his or her perception of utility and therefore this will also positively influence his or her attitude towards social commerce. According to these findings we posit that:

Hypothesis 2B: Perceived Ease of Use positively affects attitude toward using of s-commerce

The easiness of a system will affect the intention to use the system itself because if the system is too difficult to use the person will reject it (Davis, 1989). Perceived ease of use has been proved to be an effective predictor on behavioural intention in a variety of technologies in which TAM has been used: email, e-commerce, e-books or intranet (Williams et al., 2014). We therefore hypothesized:

Hypothesis 2C: Perceived Ease of Use has a positive direct effect in the behavioural intention to use of scommerce

According to Gao and Bai (2014), users will only adopt a new technology if the use of this technology provides the user with an advantage compared to similar technologies, and this is reflected in perceived usefulness construct. If the subject is able to perceive these advantages from social commerce the attitude towards social commerce and the intention to use it will be higher. In fact, scholars have been able to determine the effects of this construct on the person's intention to use new technologies like e-commerce, mobile commerce or social networks (Noh et al., 2013). According to these findings we therefore propose:

Hypothesis 3A: Perceived Usefulness has a positive direct effect on the attitude towards using scommerce

Hypothesis 3B: Perceived Usefulness has a positive direct effect on the behavioural intention to use scommerce

Attitude towards social commerce will be the propensity towards the usage of social commerce and the disposition towards the use of social commerce to purchase on the internet (Hernández-García et al., 2011). This attitude could be positive or negative (Nasri \& Charfeddine, 2012), and it will be applied in both users and non-users of social commerce. If the attitude is positive and therefore the user has a positive attitude towards social commerce his or her behavioural intention to use it will be greater and he or she will be more motivated to use social commerce (Lévy Mangin et al., 2012). According to numerous researches related to internet based services: online banking (Lévy Mangin et al., 2012), social networks (Sabir et al., 2013), Internet Of Things and mobile social commerce (Gao \& Bai, 2014) and mobile commerce (Fong \& Wong, 2015) attitude is the antecedent of behavioural intention to use and it has been confirmed to have a positive direct effect on the behavioural intention to use a system (Venkatesh \& Davis, 1996; Nasri \& Charfeddine, 2012; Sánchez et al., 2013; Wang \& Chou, 2014). We therefore hypothesized: 
Numerous studies have identified two types of system values: hedonic and utilitarian (Holsapple, 2007; Van Der Heijden, 2004; Wakefield \& Whitten, 2006), whereas hedonic systems are related to entertainment and are oriented to pleasure, utilitarian systems are more instrumental and related to productivity (Kim \& Hwang, 2012). The personalization of some features within the internet based services like e-commerce, mobile commerce or social commerce has made the systems more hedonic complementing the utilitarian value of them (usefulness, accomplishment) (Dlodlo, 2014) being the systems both useful and enjoyable (Malik et al., 2013). For these reasons when investigating the usage and adoption of social commerce we have to take into account these values because the usage tendencies of social commerce may be influenced by its hedonic or utilitarian values, and they can be important predictors of a new technology adoption (Childers et al., 2001). ). According to these findings we therefore propose the following hypotheses:

Hypothesis 5A: Utilitarian value has a positive effect on the perceived usefulness of s-commerce Hypothesis 5B: Hedonic value has a positive effect on attitude towards using s-commerce.

\section{RESEARCH METHODOLOGY AND DATA COLLECTION}

As our main goal is to analyse the adoption and usage of social commerce among the population, we have set as our target population for this research a set of people who may or may not have used social commerce and may or may not have experience with social networks or online shopping. The age range of the target population goes from 18 onwards.

For the data collection we use two methods: an online questionnaire and a paper questionnaire, both identical, based on previous investigations from a variety of scholars.

Both questionnaires, online and paper, were preceded by an explanatory paragraph on which we detailed to the people surveyed, what social commerce is. The objective of this paragraph was to create a clear concept of social commerce in the population who takes the survey. The online survey and the paper survey consist of two sections. The first section was a set of questions which helped us analyse the sociodemographic profile of the respondent and it also gave us information regarding their level of experience on social networks and online shopping, as well as on the usage of social commerce and its frequency of use. The second section was formed by a group of questions matching the constructs proposed in our model.

The sample obtained, in which we have not considered the invalid questionnaires, it is composed by 486 admitted surveys. The sample profile of participants appears in Table 1, which shows that 64 per cent of those surveyed were women and 36 per cent were men.

Table 1: Demographic and technological information of the participants.

\begin{tabular}{|l|l|}
\hline & Percentage \\
\hline Gender & \\
\hline Male & $64 \%$ \\
\hline Female & $36 \%$ \\
\hline TOTAL & $\mathbf{1 0 0 \%}$ \\
\hline Age & \\
\hline 18 to 25 & $32,8 \%$ \\
\hline 26 to 35 & $16,3 \%$ \\
\hline 36 to 45 & $18,4 \%$ \\
\hline 46 to 55 & $24,4 \%$ \\
\hline 56 to 65 & $6,5 \%$ \\
\hline 65 onwards & $1,6 \%$ \\
\hline TOTAL & $\mathbf{1 0 0 \%}$ \\
\hline
\end{tabular}




\begin{tabular}{|l|l|}
\hline Social Network users & \\
\hline Yes & $88,27 \%$ \\
\hline No & $11,73 \%$ \\
\hline TOTAL & $\mathbf{1 0 0 \%}$ \\
\hline E-commerce users & \\
\hline Yes & $84,36 \%$ \\
\hline No & $15,64 \%$ \\
\hline TOTAL & $\mathbf{1 0 0 \%}$ \\
\hline Social Commerce users & \\
\hline Yes & $50,49 \%$ \\
\hline No & $49,51 \%$ \\
\hline TOTAL & $\mathbf{1 0 0 \%}$ \\
\hline
\end{tabular}

\subsection{Reliability and validity of the scales}

The internal consistency reliability of every element it is determined by the correlations between the indicator and the latent variable, being convenient that the composite reliability is 0,7 or higher, although if it is a 0,6 value or higher is acceptable (Bagozzi \& Yi, 1988).

The convergent validity for every indicator should be 0.5 or higher (Bagozzi \& Yi, 1988). This validity will let us know if the elements of a determinate scale converge in only one construct (Sanzo et al., 2003) establishing that the variance of every construct is better explained by its measurements than by the error. Finally, the discriminant validity will be determined if the construct is better correlated with itself than with the rest of the construct, in this case Fornell and Larcker (1981) suggest that the "square root" of the Average Variance Extracted (AVE) of each latent variable should be greater than the correlations among the other latent variables, and it can be used as a criterion to measure the discriminant validity.

Table 2. Convergent validity and reliability of the internal consistency.

\begin{tabular}{|c|c|c|c|c|c|}
\hline Variable & Item & $\begin{array}{l}\text { Item } \\
\text { correlation } \\
\text { with the scale }\end{array}$ & Cronbach's Alpha & $\mathbf{C R}$ & EVA \\
\hline \multirow[t]{4}{*}{ Subjective Norms } & SN1 & 0,854 & \multirow[t]{4}{*}{0,940} & \multirow[t]{4}{*}{0,940} & \multirow[t]{4}{*}{0,796} \\
\hline & SN2 & 0,836 & & & \\
\hline & SN3 & 0,924 & & & \\
\hline & SN4 & 0,949 & & & \\
\hline \multirow[t]{4}{*}{ Perceived Ease of Use } & PEOU1 & 0,858 & \multirow[t]{4}{*}{0,897} & \multirow[t]{4}{*}{0,898} & \multirow[t]{4}{*}{0,687} \\
\hline & PEOU2 & 0,807 & & & \\
\hline & PEOU3 & 0,870 & & & \\
\hline & PEOU4 & 0,778 & & & \\
\hline \multirow[t]{4}{*}{ Perceived Usefulness } & PU1 & 0,856 & \multirow[t]{4}{*}{0,918} & \multirow[t]{4}{*}{0,919} & \multirow[t]{4}{*}{0,739} \\
\hline & PU2 & 0,888 & & & \\
\hline & PU3 & 0,883 & & & \\
\hline & PU4 & 0,808 & & & \\
\hline \multirow[t]{4}{*}{ Attitude } & ATT1 & 0,958 & \multirow[t]{4}{*}{0,943} & \multirow[t]{4}{*}{0,942} & \multirow[t]{4}{*}{0,802} \\
\hline & ATT2 & 0,893 & & & \\
\hline & ATT3 & 0,906 & & & \\
\hline & ATT4 & 0,820 & & & \\
\hline \multirow[t]{2}{*}{ Behavioural intention to use } & BI1 & 0,946 & \multirow[t]{2}{*}{0,931} & \multirow[t]{2}{*}{0,932} & \multirow[t]{2}{*}{0,820} \\
\hline & BI2 & 0,923 & & & \\
\hline
\end{tabular}




\begin{tabular}{|c|c|c|c|c|c|}
\hline & $\mathrm{BI} 3$ & 0,845 & & & \\
\hline \multirow[t]{4}{*}{ Hedonic value } & HV1 & 0,833 & \multirow[t]{4}{*}{0,935} & \multirow[t]{4}{*}{0,935} & \multirow[t]{4}{*}{0,783} \\
\hline & HV2 & 0,885 & & & \\
\hline & HV3 & 0,928 & & & \\
\hline & HV4 & 0,892 & & & \\
\hline \multirow[t]{3}{*}{ Utilitarian Value } & UV1 & 0,875 & \multirow[t]{3}{*}{0,907} & \multirow[t]{3}{*}{0,907} & \multirow[t]{3}{*}{0,764} \\
\hline & UV2 & 0,881 & & & \\
\hline & UV3 & 0,866 & & & \\
\hline
\end{tabular}

As we can see in the table above all the coefficients of the items with the scale's total are correct being greater than the minimum value indicated (0.6/0.7). The same applies to the constructs' composite reliability, it can be seen that all of the indicators have composite reliability values that are greater than the minimum acceptable level of 0,7 . These results prove that the internal consistency reliability of the model is correct.

The composite reliability and the Cronbach's Alpha of each construct are greater than the acceptable threshold of 0,7 ; therefore the discriminant validity is correct. For each construct examined, the Cronbach's Alpha is greater than 0,7; these results confirm that the items are internally consistent for each construct (Nunnally, 1978). The composite reliability is also greater than 0,7 for each construct, proving that every item within the variables are reliable (Bagozzi \& Yi, 1988). The results obtained for each AVE are above the 0,5 minimum threshold, this results show us that more than the $50 \%$ of the indicator's variance is being taken into account (Real et al., 2006). With all the results collected we therefore conclude that there is a globally convergent validity and an internal consistency among the different measurement scales proposed.

To contrast the hypotheses we used the bootstrap resampling model (4999 samples) (Henseler et al., forthcoming) in order to obtain the standard errors and the t-values. Standard errors represent the standard deviation of a statistic's distribution sampling; on the other hand, the t-values represent the significance level of the stablished relationship (for a statistical confidence level of $95 \%$, the t-value required is 1,64791345 ; for a statistical confidence level of $99 \%$ the t-value required is 2,333843952 and for a level of $99,9 \%$ de value required is 3,10; all the results above the required value will have a significant relationship).

The purpose of this system is to obtain the statistical significance of the $\beta$ coefficients (Chin, 1998). The conceptual model contrasting is shown in the figure below:

Figure 3.: The ScommAM model contrast

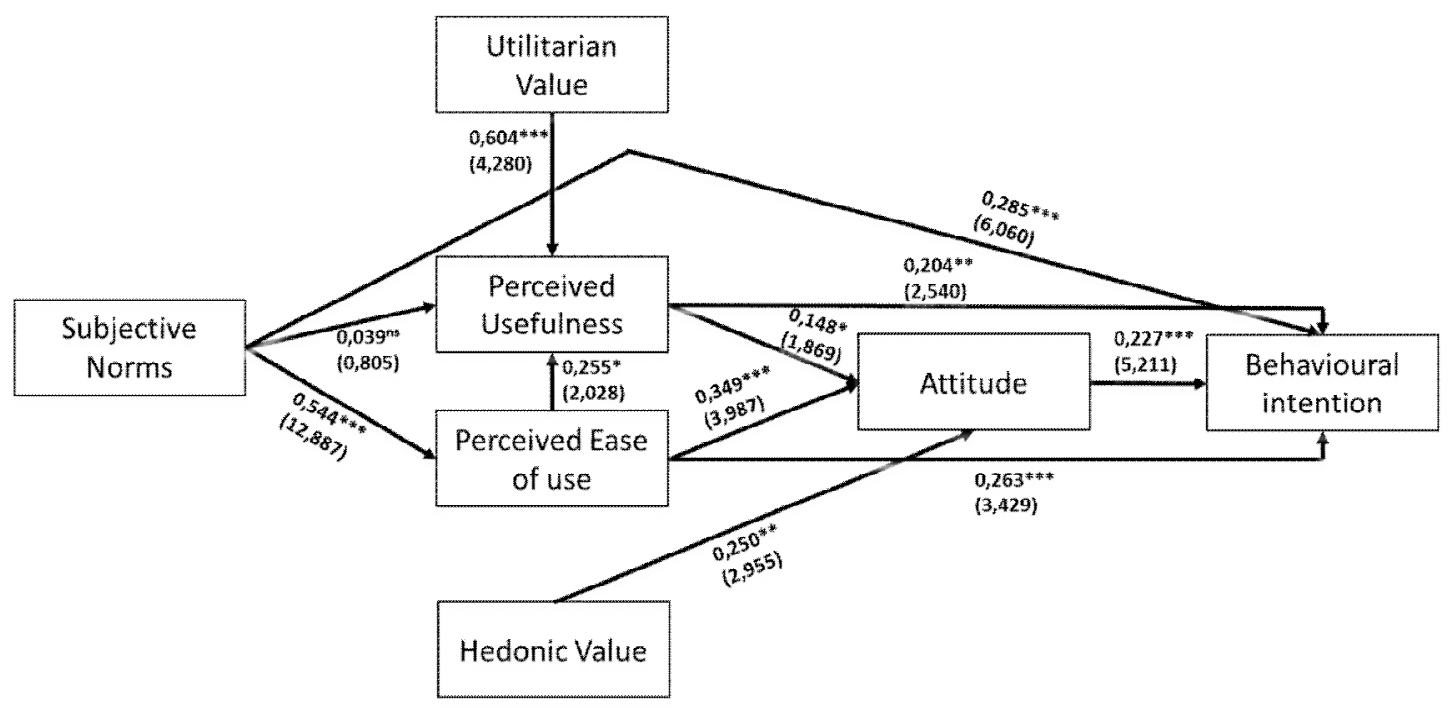

Note: Significance levels: ${ }^{* *} \mathrm{p}<0,001,{ }^{*} \mathrm{p}<0,01,{ }^{*} \mathrm{p}<0,05$, ns: not significant 
The results obtained shown that all the hypotheses were found significant except for hypothesis $1 \mathrm{C}$. The relationship between subjective norms and perceived usefulness is not significant. We believe that this finding is caused by the definition proposed of subjective norms. As we have based our acceptance model in TAM, TAM2 and UTAUT we only considered subjective norms as a variable to measure the influence of social norms on the usage of s-commerce, nevertheless, in TAM2 model, subjective norms goes hand in hand with two more variables called image and voluntariness in what Venkatesh and Davis (2000), called social influences. The same happens to UTAUT (Venkatesh, 2003), in which the influence of others on the individual are called social influence and it is composed by subjective norms, image and social factors.

As for hypothesis $1 \mathrm{~A}$ and $1 \mathrm{~B}$, when adopting social commerce the influence of subjective norms on this adoption it is directly and positive related to the behavioural intention to use social commerce. This relationship and its effect has been corroborated in other papers (Venkatesh \& Davis, 2000; Nasri \& Charfeddine, 2012; Venkatesh et al., 2012; Chong et al., 2012; Gao \& Bai, 2014). Subjective norms influence direct and positively the perceived ease of use of social commerce on the user, this finding is supported by Lu et al. (2005) or Bhatti (2007), among others.

The perceived ease of use by the user of social commerce influences the usefulness perception of it. This is because if the user perceives that social commerce is easy to use he or she will find it more useful than other online purchasing tools (Davis, 1989; Venkatesh 2000; Venkatesh \& Davis, 2000; Lim \& Ting, 2014).

Attitude towards social commerce is influenced direct and positively by perceived ease of use, therefore if social commerce is easy to use and perceived in that way the attitude towards the use of social commerce will be positive, corroborating the numerous argumentations made during this research.

When evaluating social commerce adoption the perception on the ease of use of these platforms influences direct and positively the intention to use them, this confirm what other scholars previously justify in their researches (Davis, 1989; Davis et al., 1989, Bhatti, 2007; Gao \& Bai, 2014).

Perceived usefulness has a direct and positive influence on the attitude towards the use of social commerce, this has been corroborated in previous researches mentioned in this investigation (Davis, 1989; Noh et al., 2013). It has been also proven in this research that the perception of the usefulness of social commerce positively affects the intention to use social commerce websites or platforms (Venkatesh \& Morris, 2000; Bhatti, 2007).

The attitude of the user towards the use of social commerce is an influencer on the intention to use social commerce, the more positive the attitude towards social commerce the greater the intention to use will be (Hernández-García et al., 2011; Lévy Mangin et al., 2012; Sánchez et al., 2013).

Worth to be mentioned are the significant relationships of the hedonic value and utilitarian value with the key variables of TAM attitude and perceived usefulness respectively. Although SCommA is a model unifying other technology acceptance models, both hedonic and utilitarian value were not considered in these models, so this have been a positive discovery which lead us to think that the patterns in behaviour when adopting new innovations are continuously evolving.

Table 3: Result of the structural model estimation

\begin{tabular}{|l|l|l|l|l|}
\hline Hypothesis & Sign & $\boldsymbol{\beta}$ & T-values & Valuation \\
\hline H1A: SN -> BI & + & $0,285^{* * *}$ & 6,060 & Accepted \\
\hline H1B: SN -> PU & + & $0,544^{* * *}$ & 12,887 & Accepted \\
\hline H1C: SN -> PEOU & + & $0,039^{\text {ns }}$ & 0,805 & Not accepted \\
\hline H2A: PEOU -> PU & + & $0,255^{*}$ & 2,028 & Accepted \\
\hline H2B: PEOU -> ATT & + & $0,349^{* * *}$ & 3,987 & Accepted \\
\hline H2C: PEOU -> BI & + & $0,263^{* * *}$ & 3,429 & Accepted \\
\hline H3A: PU -> ATT & + & $0,148^{*}$ & 1,869 & Accepted \\
\hline H3B: PU -> BI & + & $0,204^{* *}$ & 2,540 & Accepted \\
\hline H4: ATT -> BI & + & $0,227^{* * *}$ & 5,211 & Accepted \\
\hline H5A: UV -> PU & + & $0,604^{* * *}$ & 4,280 & Accepted \\
\hline H5B: HV -> ATT & + & $0,250^{* *}$ & 2,955 & Accepted \\
\hline
\end{tabular}

Note: Significance levels: ${ }^{* * *} \mathrm{p}<0,001,{ }^{* *} \mathrm{p}<0,01,{ }^{*} \mathrm{p}<0,05$, ns: not significant (based on $\mathrm{t}(4999)$, two tails) 


\section{CONCLUSIONS AND FUTURE RESEARCH DIRECTIONS}

The main objective of this research was to deepen in this new commercial formula which is called social commerce. As we have previously stated in this investigation the great importance of Internet and everything that surrounds it nowadays has made essential to become a part of it and to achieve what it is necessary to be always aware of the new trends and innovation in this sector. Furthermore, the rise of Web 2.0 has helped Internet to become social and that is an inexhaustible source of opportunities that companies must know how to exploit it.

The acceptance and usage of social commerce is our starting point. The variables that explain this usage and acceptance will be as we have already stated the key to understand if this internet commerce formula will be used and accepted by the consumers.

The appearance of new commercial formulas like social commerce which allows people to participate and engage in the purchase while shopping online, has the potential of changing marketing strategies (Lee, 2014) and increase e-WOM (Liébana-Cabanillas \& Villarejo-Ramos, forthcoming), this features of social commerce leads us to think that it will be a motivating power for businesses' innovations (Hajli, 2012). For these reasons we consider that social commerce needs to be explained in e-business courses as it is done with e-commerce.

Social commerce is a recently new knowledge area which needs to be payed attention by the scientific community due to its commercial potential online. Our proposal is to keep researching on this new path that has been opened in order to make the most of the knowledge extracted from these researches and apply them to the field of marketing to maximize the potential of businesses' marketing strategies.

We have based our investigation on three technology acceptance models, TAM, TAM2 and UTAUT and we have also added to the equation two variables which are much related to technology and its features, hedonic and utilitarian value. Our results have proven that the structural model works, giving us the idea of what are the influencing factors on the use of social commerce.

Innovations such as social commerce introduce in the market new ways of competitiveness among organisations, and new ways of gain competitive advantages in hypercompetitive markets like the Internet one.

The implementation of social commerce websites would help organisations increase their sources of information as the user becomes an additional source. All the comments, reviews and interactions made on the website can be crucial when making future decisions regarding new products or services. So, it becomes necessary to recreate an environment in the website which allows this features (ratings, reviews, comments on the products, recommendations of others users...).

Below these lines we will show the limitations found in this research and we posit action lines that we consider very convenient for future researches:

1) It has to be considered that the field of study contemplated in this research is very new and therefore it is difficult to find information. We believe that some of the relationships measured in this research are weaker or not significant due to the lack of scholars' references.

2) Relative to the relationship subjective norms - perceived usefulness, although the hypothesis proposed have been previously validated by others researchers, the results in our investigation showed a not significant relation among then. We therefore believe that further researches need to be done regarding this relationship and that it would be positive to transform subjective norms into social influence and consider other variables as a part of it like image or social factors (Venkatesh \& Davis, 2000; Venkatesh et al., 2003).

3) As we have obtained positive results on the relationships of hedonic and utilitarian values, it would be positive to investigate the moderating effects on gender on these relationships in order to know if the gender of the individual influences the vision of social commerce in terms of hedonism and utilitarianism. For that purpose the sample should be balanced between men and women being interesting that the percentage of men surveyed would be almost the same as the women's. 
4) For future investigations and in order to check if there are significant differences among those who has already used social commerce and those who has not, we propose to create two models: a expectation's model to study how the models behave for a sample of non-users and an experience model to study the performance of the model for experienced users. These two models will help us to identify the differences among the variables and which ones are key to adopt social commerce on each case.

The sample did not have an international respondents' representation, which reduces the reliability on the results generalisation. In future studies it can be taken into account the necessity of a bigger sample increasing the participation of international respondents in order to perform a cross-cultural research to study possible differences among nationalities on the acceptance and use of social commerce.

\section{REFERENCES}

Amin, H. (2008). Factors affecting the intentions of customers in Malaysia to use mobile phone credit cards. Management Research News, 31(7), 493-503.

Armesh, H., Saljoughi, Z.S. and Kord, B. (2010). Electronic Payment and its Implications. Interdisciplinary Journal of Contemporary Research in Business, 2(8), 246-255.

Bagozzi, R. P., and Yi, Y. (1988). On the evaluation of structural equation models. Journal of the Academy of Marketing Science, 16(1), 74-94.

Bhatti, T. (2007). Exploring Factors Influencing the Adoption of Mobile Commerce. Journal of Internet Banking and Commerce, $12(3), 1-13$

Bontis, N. and De Castro, A. (2000). The First World Congress on the Management of Electronic Commerce: review and commentary. Internet Research, 10(5), 365-373.

Cheng, Y.-M. (2011). Antecedents and consequences of e-learning acceptance. Information Systems Journal, 21, $269-99$.

Childers, T.L, Carr, C.L., Peck, J. and Carson, S. (2001). Hedonic and utilitarian motivations for online retail shopping behavior. Journal of Retailing, 77, 511-535.

Chin, W.W. (1998). The partial least squares approach for structural equation modelling. Marcoulides, G.A. (ed.) Modern Methods for Business Research; Mahwah, NJ: Lawrence Erlbaum associates pp: 295-336

Chong, A.Y.-L., Chan, F.T. and Ooi, K.-B. (2012). Predicting consumer decisions to adopt mobile commerce: cross country empirical examination between China and Malaysia. Decision Support Systems, 53(1), 34-43.

Constantinides, E. and Fountain, S. J. (2008). Web 2.0: conceptual foundations and marketing issues. Journal of Direct, Data and Digital Marketing Practice, 9(3), 231-244.

Constantinides, E.; Lorenzo, C. and Gómez, M.A (2008). Social Media: A New Frontier for Retailers? European Retail Research, $22,1-28$.

Curty, R.G. and Zhang, P. (2011). Social Commerce: Looking Back and Forward. ASIST 2011, October 9-13, 2011, New Orleans, LA, USA.

Davis, F.D. (1989). Perceived Usefulness, Perceived Ease Of Use, And User Acceptance of Information Technology. MIS Quarterly, 13(3), 319-340.

Dlodlo, N. (2014). Developing an Online Shopping Value Framework for Consumers of Non-Store Fashion Brands. International Business \& Economics Research Journal, 13(6), 1359-1374.

Fong, K.K. and Wong, S.K.S. (2015). Factors Influencing the Behavior Intention of Mobile Commerce Service Users: An Exploratory Study in Hong Kong. International Journal of Business and Management, 10(7), 39-47.

Fornell, C., and Larcker, D.F., (1981). Evaluating structural equation models with unobservable variables and measurement error. Journal of Marketing Research, 18 (1), 39-50.

Gao, L. and Bai, X. (2014). A unified perspective on the factors influencing consumer acceptance of internet of things technology. Asia Pacific Journal of Marketing and Logistics, 26(2), 211-231.

Gao, L. and Bai, X. (2014). An empirical study on continuance intention of mobile social networking services Integrating the IS success model, network externalities and flow theory. Asia Pacific Journal of Marketing and Logistics, 26(2), 168-189.

Hajli, M. (2012). A research framework for social commerce adoption. Information Management \& Computer Security, 21(3), 144154 
Hajli, M. (2012). An Integrated Model for E-commerce Adoption at the Customer Level with the Impact of Social Commerce. International Journal of Information Science and Management, Special Issue (ECDC), 77-97.

Hajli, M., Hajli, M., Khani, F. (2013). Establishing Trust in Social Commerce through Social Word of Mouth. 7th International Conference on e-Commerce in Developing Countries: With Focus on e-Security (ECDC), 1-22.

Hassouneh, D. and Brengman, M. (2011). Shopping in virtual worlds: perceptions, motivations, and behavior. Journal of Electronic Commerce Research, 12(4), 320-335.

Henseler, J.; Hubbona, G. and Ash Ray, P. (forthcoming). Using PLS Path Modelling in New Technology Research: Updated Guidelines. Accepted for publication in Industrial Management \& Data Systems.

Hernández-García, A., Iglesias-Pradas, S., Chaparro-Peláez, J., Pascual-Miguel, F. (2011). Exploring the Attitudes and Intentions of Non-shoppers in the Acceptance of e-Commerce. Journal of Universal Computer Science, 17(9), 1314-1328.

Holsapple, C. W. (2007). User acceptance of virtual worlds: the hedonic framework. Database for Advances in Information Systems, 38(4), 86-89.

Huang, Z. and Benyoucef, M. (2013). From e-commerce to social commerce: A close look at design features. Electronic Commerce Research and Applications, 12, 246-259.

Hughes, S. and Beukes, C. (2012). Growth and implications of social e-commerce and group buying daily deal sites: the case of Groupon and LivingSocial. International Business \& Economics Research Journal, 11(8), 921-934.

Hughes, S. and Breytenbach, C. (2013). Groupon's growth and globalization strategy: structural and technological implications of international markets. International Business \& Economics Research Journal, 12(12), 1589-1604.

Kim, D.J. and Hwang, Y. (2012). A study of mobile internet user's service quality perceptions from a user's utilitarian and hedonic value tendency perspectives. Information Systems Frontiers 14(2), 409-421.

Kim, Y.A. and Srivastava, J. (2007). Impact of social influence in e-commerce decision making. ICEC'07, August 19-22, 2007, Minneapolis, Minnesota, USA.

Kleijnen, M., Wetzels, M. and De Ruyter, K. (2004). Consumer acceptance of wireless finance. Journal of Financial Services Marketing, 8(3), 206-17.

Kuthiala, S K. (2003). E-commerce in India: challenges and choices. Journal of Services Research, 2(2), 139-155.

Lee, I. (2014). A collaborative management of social commerce deals: Decisions on pricing and commission rate with a capacity consideration. Journal of Revenue and Pricing Management, 13(3), 233-246

Lee, M.-Y., Kim, Y.-K. and Lee, H.-J. (2013). Adventure versus gratification: emotional shopping in online auctions. European Journal of Marketing, 47(1/2), 49-70

Lee, S. H., DeWester, D. and Park, S. R. (2008). Web 2.0 and opportunities for small business. Service Business, 2(4), $335-345$.

Lévy Mangin, J.-P., Bourgault, N. and Moriano León, J. (2012).Testing Control, Innovation and Enjoy as External Variables to the Technology Acceptance Model in a North American French Banking Environment. International Business Research, 5(2), $13-26$

Liang, T.-P. and Turban, E. (2011). Introduction to the Special Issue Social Commerce: A Research Framework for Social Commerce. International Journal of Electronic Commerce, 16(2), 5-13.

Liao, S. and Chu, H. (2013). Influence of consumer online resale awareness on purchase decisions: a mental accounting perspective. European Journal of Marketing, 47(10), 1576-1597.

Liébana-Cabanillas, F. and Villarejo-Ramos, A. F. (2015). Applications of mobile social networks: consumer behavior in mobile social commerce. Forthcoming.

Liébana-Cabanillas, F., Villarejo-Ramos, A.F. (2014a). Mobile social commerce acceptance model: factors and influences on intention to use s-commerce European Marketing Academy Congress, June, Valencia (Spain).

Lim, W.M. and Ting, D.H. (2014). Consumer acceptance and continuance of online group buying. The Journal of Computer Information Systems, 54(3), 87-96.

Lu, J., Yao, J.E. and Yu, C.-S. (2005). Personal innovativeness, social influences and adoption of wireless Internet services via mobile technology. Journal of Strategic Information Systems, 14, 245-268.

Malik, A., Kumra, R., Srivastava, V. (2013). Determinants of Consumer Acceptance of M-Commerce. South Asian Journal of Management, 20(2), 102-126.

Marsden, P. (2009). How Social Commerce Works: The Social Psychology of Social Shopping. Social Commerce Today, Syzygy London, London, UK. Available at: http://www.digitalintelligencetoday.com/how-social-commerce-works-the-socialpsychology-of-social-shopping/ 
Nasri, W. and Charfeddine, L. (2012). An Exploration of Facebook.Com Adoption in Tunisia Using Technology Acceptance Model (TAM) and Theory of Reasoned Action (TRA). Interdisciplinary Journal of Contemporary Research in Business, 4(5), 948968

Noh, M., Lee, K., Kim, S., Garrison, G. (2013). Effects of collectivism on actual s-commerce use and the moderating effect of price consciousness. Journal of Electronic Commerce Research, 14(3), 244-260.

Nunally, J.C. (1978). Psychometric theory. New York: McGraw-Hill.

Nysveen, H. (2005). Intentions to use mobile services: antecedents and cross-service comparisons. Journal of the Academy of Marketing Science, 33(3), 330-46.

Ozen, H. and Engizek, N. (2014). Shopping online without thinking: being emotional or rational? Asia Pacific Journal of Marketing and Logistics, 26(1), 78-93

Real, J.C, Leal, A. and Roldán, J.L. (2006). Information technology as a determinant of organizational learning and technological distinctive competencies. Industrial Marketing Management, 35(4), 505-521.

Sabir, R.J., Ahmad, W., Noor, N., Rehman, A. (2013). Adoption of Social Networking Sites among Pakistani University Students: A Case of Face-Book. Journal of Asian Business Strategy, 3(6), 125-139.

Sanzo, M.J.; Santos, M.L.; Vázquez, R. and Álvarez, L.I. (2003). The effect of market orientation on buyer-seller relationship satisfaction. Industrial Marketing Management, 32(4), 327-345.

Sharma, A. and Sheth, J.N. (2004). Web-based marketing the coming revolution in marketing thought and strategy. Journal of Business Research, 57, 696-702.

Stephen, A.T. and Toubia O. (2010). Deriving Value from Social Commerce Networks. Journal of Marketing Research, 47, 215228

Sun, H. (2011).Designing for Social Commerce Experience as Cultural Consumption. Lecture Notes in Computer Science, 6775, 402-406.

Van der Heijden, H. (2004). User acceptance of hedonic information Systems. MIS Quarterly, 28(4), 695-704.

Venkatesh, V. and Davis. F.D. (2000). A Theoretical Extension of the Technology Acceptance Model: Four Longitudinal Field Studies. Management Science 46(2), 186-204.

Venkatesh, V., Morris, M.G., Davis, G.B. and Davis, F.D. (2003). User acceptance of information technology: Toward a unified view. MIS quarterly, 27(3), 425-478.

Venkatesh, V., Thong, J.Y.L. and Xu, X. (2012). Consumer acceptance and use of information technology: extending the Unified Theory of Acceptance and Use of Technology. MIS Quarterly, 36(1), 157-178.

Wakefield, R. L., and Whitten, D. (2006). Mobile computing: a user study on hedonic/utilitarian mobile device usage. European Journal of Information Systems, 15, 292-300.

Wang, E.T. and Chou, N.P. (2014). Consumer characteristics, social influence, and system factors on online group-buying repurchasing intention. Journal of Electronic Commerce Research, 15(2), 119-132.

Wattanasupachoke, T. (2011). Success Factors of Online Social Networks. Journal of Global Business Issues, 5(2), 11-21.

Williams, M.D., Slade, E.L., Dwivedi, Y.K. (2014). Consumer's intentions to use e-readers. The Journal of Computer Information Systems, 54(2), 66-76.

Yang, K. and Lee, H.-Y. (2010). Gender differences in using mobile data services: utilitarian and hedonic value approaches. Journal of Research in Interactive Marketing, 4(2), 142-156. 